\title{
The Interaction of Polymetaphosphates with Hide Protein*
}

\author{
K. H. GUSTAVSON and ALVAR LARSSON \\ Garverinäringens Forskningsinstitut, Stockholm, and C. J. Lundbergs Läderfabriks AB, \\ Valdemarsvik, Sueden
}

$T$ The protein-precipitating faculty of metaphosphoric acids has long been known, first observed by Berzelius in 1816; also the more pronounced effect of acidified solutions of polymetaphosphates (= PMP) was found far back. However, these reactions received serious attention first some 25 years ago. In the intervening years a number of investigations of various PMP protein systems are to be recorded. Since the chemistry of the condensed phosphate compounds, particularly that of the commonly employed "hexametaphosphate" (Graham's salt) is in itself exceedingly complicated, that being the case with polyacids generally, the inclusion of the elusive proteins in the system makes the problem still more difficult. The aqueous solutions of PMP, mostly applied after adjustment to $\mathrm{pH}$ values of $2-3$, show continued alterations of the solute. In fact, very little is known about the composition and the molecular weight distribution of acidified PMP solutions.

The interaction of PMP and its acids with globular proteins has been investigated by Schofield ${ }^{1}$, Perlmann ${ }^{2}$, Briggs ${ }^{3}$ and their coworkers. Thus, Perlmann and Hermann ${ }^{4}$ showed that metaphosphoric acid combines stoichiometrically with the basic protein groups of egg albumin. Further, Perlmann applied this reaction for estimating the acid binding capacity of various proteins. Already in 1935, Schofield pointed out that the titration of ionizable amino groups of proteins would be considerably simplified by the use of an acid with its anion becoming firmly bound to the basic protein groups; suggesting metaphosphoric acid or its polymers as a suitable agent. The importance of the anion affinity for the interaction of acids with proteins has been convincingly proved by the fundamental researches of Steinhardt ${ }^{27}$.

\footnotetext{
* The main findings of this paper were presented in a lecture given by the senior author at the meeting of the Nordic Leather Chemists' Association in Gothenburg, June 9, 1949. 
The reactions of PMP are also of importance for fibrous proteins, particularly collagen. PMP of the type of Graham's salt, applied in acidic solution, possess marked affinity for hide protein, exerting a peculiar tanning action. Even at $\mathrm{pH}$ values corresponding to the maximum swelling of the hide protein by strong mineral acids, $i . e ., \mathrm{pH}$ 1.5-2.0, the PMP acids do not swell the hide structure, rather dehydrate it; the main part of the PMP taken up by collagen being irreversibly fixed. Hence it is not removed by prolonged extraction with water. This peculiar property of acidified solutions of PMP, discovered by Wilson ${ }^{6}$, has already obtained important practical applications in pretreatment of neutral pelt (dehaired, alkali-treated ("limed") and further purified skins and hides) for the tanning processes. Wilson found that the PMP acids interacted with the basic protein groups. He conceived the reaction to be an electrovalent attachment of a chainlike PMP-molecule with regularly interspaced ionic groups, $-\prod_{0}^{-}-P_{-}^{-}-0-$, to the cationic protein groups of adjacent collagen chains.

The PMP-collagen system has further been studied by Riess ${ }^{6}$, Schneider ${ }^{7}$, Lindner ${ }^{8}$ and Salo ${ }^{9}$. On the whole their results agree with the original findings and the conception of Wilson. Schneider has demonstrated the easy displacement of fixed PMP from its combination with collagen by means of sodium chloride of $2 M$ strength; a phenomenon earlier encountered with globular proteins ${ }^{4}$. Salo has shown that by deamination of collagen its binding capacity for PMP is lowered directly in proportion to the amount of amino groups removed; forming an additional proof of the stoichiometric nature of the reaction.

PMP is believed to be the best reagent known for evaluation of the number of cationic groups of proteins. In the light of the findings to be presented, it must be cautioned against uncritical application of this reaction, since steric factors enter in the reactions of the high-molecular acids of PMP with collagen, as the accessibility of the cationic protein groups to the numerous anionic loci of the large PMP molecule. This will make the reaction mechanism more complicated because a number of the anionic centers of the PMP structure are not able to react with the basic protein groups. Further, it will be shown that in systems of sodium polymetaphosphate, adjusted to $\mathrm{pH}$ values of $2.0-4.5$ with hydrochloric acid, the anions removed by collagen contain not only - $\mathrm{OH}$ - groups but also - $\mathrm{ONa}$ - groups which latter do not interact with collagen. As evident from the literature, the question whether the acid as such is bound irreversibly by collagen or anions containing sodium in the form of - ONa links are taken up by collagen from solutions of acidified 
sodium PMP, in the $\mathrm{pH}$ range $2.0-3.5$ usually employed, is not settled. Riess ${ }^{6}$ believed the latter type of anions to be involved in the fixation, whereas Schneider ${ }^{7}$ takes the opposite view. No binding experimental evidences for any of the contrary views have been adduced by any of these workers; the data supplied by Riess being inadequate and inconclusive, as pointed out by Schneider. In the present paper the fixation of large PMP anions containing sodium has been proved experimentally by two independent methods.

\section{SOME RELEVANT POINTS OF THE CHEMISTRY OF PMP}

In the investigations of the PMP-protein systems reviewed, the Graham salt was assumed to be the hexa-compound and the corresponding acid or its split-up products (including the monomer) to be taken up by the protein. The literature of the condensed phosphates up to 1940 is reviewed in the monograph of Karbe and Jander ${ }^{10}$ and the researches of the last decade in the clarifying papers of Van Wazer ${ }^{11}$. Only some main issues of importance for the understanding of the behaviour of PMP towards collagen will be accentuated in this connection.

As already mentioned, Wilson ${ }^{5}$ was the first to conceive Graham's salt and the corresponding acid to consist of long chain-like molecules, interacting with the cationic groups of collagen by means of the numerous $-\mathrm{P}-\mathrm{O}^{-}$ groups of the PMP chain. Important experimental evidence for the highmolecular nature of some types of Graham's salt was offered by Samuelson ${ }^{12}$ who pictures the acid of the PMP as mixtures of long chain polyphosphate:<smiles>O=P(O)(O)OP(=O)(O)OP(=O)(O)OP(=O)(O)O</smiles>

The terminal OH-groups (in italics) are weak acid groups whereas the regularly interspaced $\mathrm{OH}$-groups show strong acidic function. This difference in strength of the OH-groups forms the basis for the determination of the molecular weight of PMP by the end group method of Samuelson ${ }^{12}$; the weak acid groups titrating in the $\mathrm{pH}$ interval 5.5-8.5. An electrometric titration is shown in Fig. 1, curve $I$. 
For a pure anhydrous Na-PMP, with no rings or orthophosphate present, the average chain length, $n$, is:

$$
n=\frac{2 \text { (equivalents of strong acid groups) }}{\text { equivalents of titrated weak acid groups }}
$$

Titrating a solution of $1.02 \mathrm{~g}\left(\mathrm{NaPO}_{3}\right)_{n}$, as applied in the present investigation, and $a \mathrm{ml} 0.1 \mathrm{~N} \mathrm{NaOH}$ being consumed in the end group titration, the molecular weight will be:

$$
M=\frac{20400}{a}
$$

since $M=102 n$ and further since $M=\frac{2 \times 102 \times 100}{a}$. The values of $M$ obtained by means of this method are of the same order of magnitude as those derived from physico-chemical methods (diffusion ${ }^{10}$ and ultracentrifugal ${ }^{21}$ ). Further, the fundamental researches of Van Wazer ${ }^{11}$, particularly his findings of the distribution of $\mathrm{M}$ in acetone fractionated PMP, add strength to this conception of the structure of PMP and to the justification of the end group method. Van Wazer found that in solution of Graham's salt with large average chain length $(n=193)$ the fractionation follows the distribution curve derived for a random reorganization process. He also offered the first proof of the existence of phosphato-sodium complexes, probably chelate rings of the type:<smiles></smiles>

Another cardinal point of the long-chain structure concept, relevant to the interaction of acidified solutions of Graham's salt with proteins, concerns the gradual displacement of the $\mathrm{Na}$ ions in the PMP chain by $\mathrm{H}$ ions with increasing $\mathrm{H}$ ion concentration of the system. This formation of chains with $\mathrm{Na}$ and $\mathrm{H}$ ions alternating as compensators of the regularly occurring $-\mathrm{P}-\mathrm{O}^{-}$ groups, with the ratio of $\mathrm{Na}$ to $\mathrm{H}$ governed by the $\mathrm{pH}$ of the system, will explain some enigmatic findings of the variations of the equivalent weight of the PMP fixed by proteins. This is brought out by the data of this paper. Further, the average chain length of acidified PMP solutions as a function of time is a paramount issue as well as the molecular size of the PMP combined irreversibly with the protein, which problems are very difficult experimentally. 


\section{SCOPE OF THIS WORK}

A number of problems pertaining to the reaction mechanism have been studied. Since the interaction of PMP with an insoluble protein like collagen in many respects offers better experimental possibilities than watersoluble globular proteins, the behaviour of collagen towards the PMP compounds should be expected to advance our knowledge of these complicated systems. The importance of theoretical fundamentals for rational technical application of PMP to various tanning processes is obvious.

In the present paper, the results from investigations of the fixation of PMP-compounds by collagen from solutions of sodium polymetaphosphate, adjusted to $\mathrm{pH}$ values in the range 1.4 to 5.8 by the addition of hydrochloric acid, are reported. Further, data on the interaction of ion-exchanged PMPacids, free from foreign ions, with collagen at various $\mathrm{pH}$-values are included as well as experimental findings pertaining to the chemical composition of the PMP fixed by collagen, its average molecular size and mode of binding, particularly its degree of stability towards sodium chloride. By measuring the changes in hydrothermal stability of collagen as a result of its fixation of PMP-compounds, a deeper insight into the mechanism of the reaction is to be expected.

The main themes to be discussed are the effect of the $\mathrm{H}$-ion concentration on the irreversible fixation of PMP by collagen and the stability of the compounds formed. According to the literature, the maximum fixation of PMP from acidified solutions of the sodium salt of PMP (Graham's salt) occurs at an equilibrium $\mathrm{pH}$ value of 2.4. With further decrease of $\mathrm{pH}$ a very marked lowering of fixed $\mathrm{P}$ is generally reported. This is indeed an exceptional behaviour of a strong acid, with its anion exhibiting extraordinary affinity for the cationic protein groups. In previous known cases the fixation of such anion-combining acids shows a broad maximum zone in the $\mathrm{pH}$ range $1-3$, whereas strong acids containing anions with little or no affinity for the basic protein groups and hence present in reversible combination with the proteins, show a steady increase of fixation until the $\mathrm{pH}$ corresponding to the maximum binding capacity of the protein for $\mathrm{H}$-ions is reached. Since in the investigations of the workers mentioned the equivalents of PMP fixed by the protein have been obtained from determination of the $\mathrm{P}$ content of the treated proteins without due consideration of the existence of $\mathrm{P}$ groups of the PMP chains holding - $\mathrm{ONa}$ - -groups, non-reactive towards the protein, the data of the literature are misleading. In other words, the figures obtained from the $\mathrm{P}$ content of collagen containing anions of PMP taken up from the system: $\left(\mathrm{NaPO}_{3}\right)+\mathrm{HCl}$ show varying equivalent weights of $\mathrm{P}$, from about 40 to 90 
according to the $\mathrm{pH}$ of the system, the lower values recorded at $1: 1$ ratio of the components ( $\mathrm{pH}$ 1.3) and the higher values for systems of high $\mathrm{pH}$ values, for instance 5. By means of indirect determination of the equivalent fixation of PMP (alkalimetric titration of the original and residual solutions of PMP), an evaluation of the degree of inactivation of the basic protein groups is possible. The uptake of ion-exchanged PMP-acid by collagen as a function of the final $\mathrm{pH}$ of the system shows the regular trend of the fixation of strong acids by proteins, i.e., steady increased fixation by lowering the $\mathrm{pH}$. This also applies to data from the direct $\mathrm{P}$ determination, since complications due to varying $\mathrm{Na}$ content and equivalent weight of $\mathrm{P}$ of the chains are excluded.

\section{MATERIALS AND METHODS}

American standard hide powder and iso-electric calf skin pelt (limed and subsequently delimed) served as substrates see 13 . The maximum binding capacity of these specimens for hydrochloric acid were 0.90 and 0.94 meq $\mathrm{H}^{+}$per g collagen $(1.0 \mathrm{~g}$ collagen in $25.0 \mathrm{ml}$ $0.1 \mathrm{~N}$ solution of $\mathrm{HCl}$, containing 2 vol. $\% \mathrm{NaCl} 24 \mathrm{~h}$ ) and the $\mathrm{N}$ contents: 18.0 and 18.1, respectively. A number of sodium polymetaphosphates (Graham's salt) were investigated in the early stage of the work; the main series being carried out with products manufactured by Reymersholms Gamla Industrialtiebolag, Hälsingborg. The standard preparations contained $68.4 \% \mathrm{P}_{2} \mathrm{O}_{5}$. The Graham salt was dissolved in cold water to yield a $10.2 \%$ solution of $\mathrm{NaPO}_{3}(1 \mathrm{~N})$. The $\mathrm{pH}$ of the $0.1 \mathrm{~N}$ solution was 5.6-5.8. The average molecular weight of the PMP:s used in the early work was 6800 , determined by the end group method of Samuelson ${ }^{12}$ whereas the product used in recent years showed an average value of 3600 . The average molecular weights of the sodium polymetaphosphates employed are given in Table 1. No marked difference was found in the degree of fixation of the various preparations by hide powder from solutions with final $\mathrm{pH}$ values in the range 2.4-4.0, although the degree of stability of the fixed PMP generally decreased with lowering of the molecular weight. In solutions of final $\mathrm{pH}$ values below 2 , the low molecular preparations showed lower degree of irreversible fixation, a marked tendency of instability upon prolonged washing of the PMP-collagen, lesser power of hydrothermal stabilization of collagen and in some instances, a marked tendency of swelling the protein.

Since in the most highly acidified solutions of PMP splitting of the larger units into smaller ones rapidly takes place, the time factor is of utmost importance ${ }^{14}$. In strongly acid systems brief periods of interaction of the PMP-acids with the protein $(2-6 \mathrm{~h})$ must be adhered to; rather two consecutive treatments with freshly prepared solutions for 2-4 h each time. Employing finely divided hide powder, in order to eliminate topochemical complications as far as possible, this time of interaction affords attainment of final equilibrium and complete inactivation of the basic protein groups. As a rule, about $90-95 \%$ of the saturation value of the PMP fixation is reached upon two $h$ violent

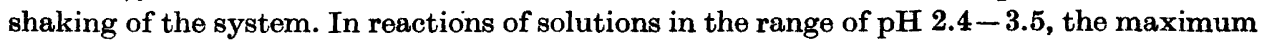
fixation is generally obtained upon $12 \mathrm{~h}$ interaction in one operation. 
Table 1. Average molecular weights of sodium polymetaphosphates. (Samuelson's end group method 12).

\begin{tabular}{lcc} 
No. $\quad$ Manufacture & $\begin{array}{c}\text { Molecular } \\
\text { weight }\end{array}$ & $\begin{array}{c}\text { Number of } \\
\mathrm{PO}_{3} \text {-units }\end{array}$ \\
\hline 1. Calgon, Inc. Pittsburgh, $\mathrm{Pa}$ & 1250 & 12 \\
2. Merck (1944) & 2600 & $\mathbf{2 5}$ \\
3. Reymersholm (1945) & 6800 & 66 \\
4. Reymersholm (1947) & 3600 & 35 \\
5. Own preparation (fused at $800^{\circ} \mathrm{C}$ ) & 7600 & 75 \\
6. Own preparation from $\mathrm{P}_{2} \mathrm{O}_{5}$ in ether-water (cooled); & & \\
subsequently neutralized by means of $\mathrm{NaOH}$ & 1200 & 12 \\
\hline
\end{tabular}

An approximation of the size distribution of the PMP used was obtained by gradual precipitation of aqueous solutions of sample no. 3 (average $n=66$ ) by means of acetone, according to the method of Van Wazer (11). The end group determinations of $n$ of the various fractions and their percentages of the total $P$ gave: 120 and $25 ; 80$ and $34 ; 35$ and 29 and finally 15 units in the fraction containing $12 \%$ of the total $\mathrm{P}$. These figures are not corrected for the presence of rings (e. g., trimeta), since the original preparation contained less than $2 \%$ of the total $\mathbf{P}$ in this form $(C f(11))$.

The determination of the molecular weight according to the end group method of Samuelson ${ }^{12}$ was carried out by electrometric titration of $1.02 \mathrm{~g}$ of the sodium compound dissolved in $100 \mathrm{ml}$ water at $20^{\circ} \mathrm{C}$, noting the consumption of $0.1 \mathrm{~N} \mathrm{NaOH}$ in the $\mathrm{pH}$ range from 5.6-5.8 to 8.5-8.6. Curve I of Fig. 1 shows the end group titration of specimen no. 3. Since in the present instance some idea of the average molecular weight of the specimens present in the acidified solutions was pertinent, the end group determinations were carried out on solutions of sodium polymetaphosphate adjusted to $\mathrm{pH}$ values of 2.0, 3.0 and 4.0, after various time of standing. The end group titrations of PMP no. 3, adjusted to $\mathrm{pH} 3.0$ by means of $\mathrm{HCl}$ and kept at various periods at this $\mathrm{pH}$, are graphically given in Fig. 1. Applying the method of Lowry and Lopez ${ }^{15}$ to these solutions, simple phosphate ions were shown to be absent even after $24 \mathrm{~h}$ keeping. The curves of Fig. 2 show the general effect of decreasing $\mathrm{pH}$ of the system on the average molecular weights of the PMP $(M=6800)$. Acidifying by means of formic acid seems to give more stable solutions of PMP at $\mathrm{pH}>2$ than the $\mathrm{HCl}$-adjusted solutions. Practical experience from pretreatment of skins in solutions of acidified PMP has also proved the superiority of formic acid as a pH-adjusting agent in regards to stability of the solutions of PMP. 


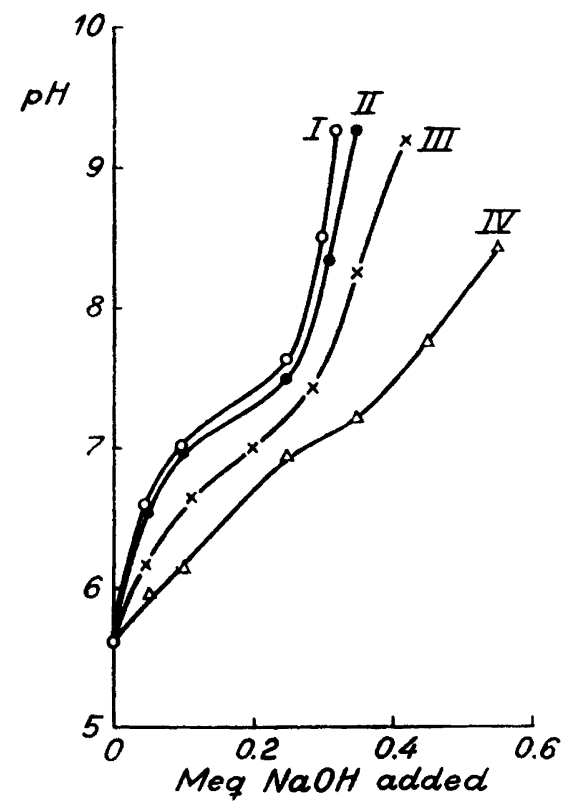

Fig. 1. End group titration of $1 \mathrm{~g}$ sodium polymetaphosphate in $100 \mathrm{ml}$ water, adjusted to $\mathrm{pH} 3.0(\mathrm{HCl})$, after keeping the solutions for various periods of time. Solutions kept:

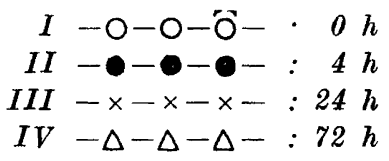

Polymetaphosphoric acid of $0.1 \mathrm{~N}$ strength was made by percolating $25.0 \mathrm{ml} 10.2$ per cent $\mathrm{NaPO}_{3}$-solution, diluted with $75 \mathrm{ml}$ water through a column of $\mathrm{H}$-ion charged Dowex-50 (30 g with 165 meq capacity for $\mathrm{Na}^{+}$) in $10 \mathrm{~min}$. The filtrate and washings were made up to $250 \mathrm{ml}$. The solutions which were used immediately after preparation were exactly $0.100 \mathrm{~N}$ (methyl red).

The standard technique employed for the interaction of PMP with collagen was as follows: $2.0 \mathrm{~g}$ collagen in the form of hide powder was soaked in $20 \mathrm{ml}$ water $2 \mathrm{~h}$ previous to the experiment. Portions of polymetaphosphate equal to $1 \mathrm{~g} \mathrm{NaPO}$ in total volume of $50 \mathrm{ml}$, adjusted to the desired $\mathrm{pH}$ values by means of $0.1 \mathrm{~N}$ hydrochloric acid, were added and the system shaken $4 \mathrm{~h}$. At least duplicates were run. In the first the $\mathrm{pH}$ value of the residual solution was determined. The treated collagen was then washed, drummed and shaken out with water (2 l) in order to remove loosely attached PMP. The stock was sucked dry, dehydrated by means of acetone, dried and analyzed for $\mathrm{P}$ and collagen. In some instances the Na-content of the stock was determined by the Lundegårdh spectrometric method $16 *$. The second sample was washed on a glass filter, the solutions and washings made up to $1000 \mathrm{ml}$. The hide powder was then acetone dehydrated, dried and analyzed like the first one. Aliquots of the collected effluents were titrated with $0.1 \mathrm{~N}$ $\mathrm{NaOH}$ (methyl red and phenolphthalein) and the former figure used in the "by difference" determination of the amount of removed acid (the total equivalent of acid of the original solution - the equivalents of acid present in the residual solution (methyl red figures).

* The kind cooperation of Dr. I. Ekdahl is gratefully acknowledged. 


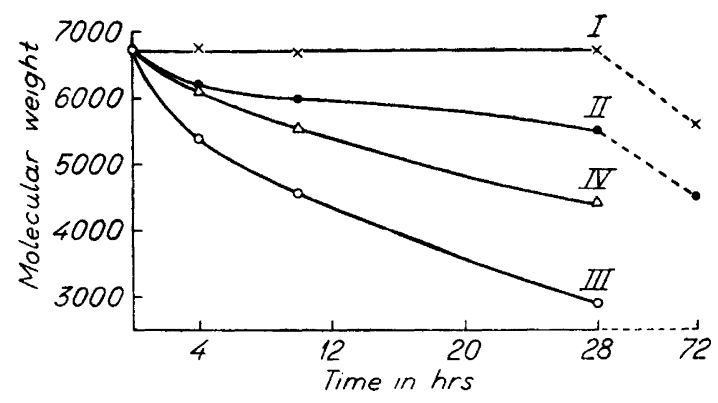

Fig. 2. The average molecular weight of sodium polymetaphosphate in $1 \%$ solution, adjusted to $\mathrm{pH}$ values of: 2.0, 3.0 and 4.0 by means of $\mathrm{HCl}$, kept at various periods of time, determined by end group titration.

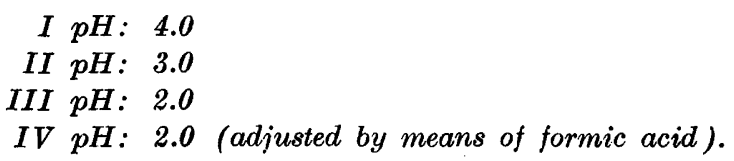

In some experiments, portions of hide powder equal to $1 \mathrm{~g}$ collagen were treated in $25.0 \mathrm{ml} 1.0 \%$ solution of PMP in order to increase the accuracy of the indirect method. Further, in the series with ion-exchanged acid of PMP (Fig. 3) $1 \mathrm{~g}$ collagen was treated in $50 \mathrm{ml}$ portions of solutions of normalities $0.1-0.04$ and in $100 \mathrm{ml}$ portions of solutions of $0.03-0.01$ normality, in order to obtain data in the higher $\mathrm{pH}$ range.

For the determination of the amount of combined PMP (determined and given as P), $0.2 \mathrm{~g}$ dry phosphated hide powder was digested for $20 \mathrm{~min}$ in a Kjeldahl flask with $15 \mathrm{ml}$ sulphuric acid (1.84) and $5 \mathrm{~g}$ anhydrous sodium sulphate, using $50 \mathrm{mg}$ selenium as catalyst. The digest was made up to $200 \mathrm{ml}$ and $2.0 \mathrm{ml}$ of this solution was used for P-determination. This was carried out in a Spekker photoelectric absorptiometer, employing the "molybdenum blue" method ${ }^{17}$. Particulars regarding special techniques and other details will be given in connection with the experimental data.

\section{RESULTS}

1. The effect of $p H$ upon the reaction.

Fig. 3 shows the irreversible fixation of polymetaphosphoric acid, prepared by ion exchange, by collagen (hide powder) after $12 \mathrm{~h}$ interaction in the terms of meq acid fixed by $1 \mathrm{~g}$ collagen, determined indirectly from the difference in acid content of the original and residual solutions (methyl red) and directly by P-determination of the treated collagen preparations. The results of the two methods agree well. The steady increase of fixed $\mathrm{P}$ with increasing $\mathrm{H}$-ion concentration is clearly brought out by the curves. Important to note is that such large amounts as 1.4 meq PMP acid per g collagen are recorded whereas 
the amount of cationic protein groups is only about 0.94 meq. Since the maximum binding capacity of collagen was attained at. the low $\mathrm{pH}$ values, the results indicate that only about two thirds of the anionic centers of PMP are discharged by the basic protein groups. In Fig. 4 the corresponding curves depicting the irreversible combination of PMP-anions from solutions of $2 \%$ strength in $\mathrm{NaPO}_{3}$ adjusted to $\mathrm{pH}$ values from 1.4 to 5.6 are given after $12 \mathrm{~h}$ interaction, leading to attainment of equilibrium. A marked divergency of the two curves is shown particularly in the higher $\mathrm{pH}$ range. Thus, for instance at a final $\mathrm{pH}$ value of 4.6, the amount of $\mathrm{P}$ in the phosphated collagen corresponds to 0.81 meq. PMP whereas the alkalimetric titration gives only 0.40 meq. On the other hand at a $\mathrm{pH}$ value of 1.3 with equivalent amounts of $\mathrm{HCl}$ and $\mathrm{NaPO}_{3}$ present, the corresponding values are 1.38 and 1.30. The total Cl-content introduced with the hydrochloric acid was quantitatively accounted for in the analysis of the residual solutions. Hence, no hydrochloric acid is taken up by the protein under these conditions. Further, as will be shown by results from separate series given in the following, hide powder treated in solutions of $\mathrm{pH}$ values exceeding 2 contains considerable amounts of sodium.

Thus, PMP-hide powder was obtained by treating $25 \mathrm{~g}$ collagen as hide powder, hydrated in $200 \mathrm{ml}$ water, in a final volume of $500 \mathrm{ml}$ of $2 \%$ sodium polymetaphosphate (M.W. 6800) for 6 h, adjusted to an initial pH of 2.4 and yielding a final $\mathrm{pH}$ of 3.4. The treated hide powder was then lightly washed and sucked to dryness. It was then immediately treated for $12 \mathrm{~h}$ in $400 \mathrm{ml}$ of a $2 \% \mathrm{NaPO}_{3}$ solution of $\mathrm{pH} 2.0$. The final $\mathrm{pH}$ was 2.4. It was washed until the wash water gave negative $P$ test (after acid hydrolysis), sucked dry, dehydrated in $200 \mathrm{ml}$ acetone and airdried. It contained, figured on dry substance: $4.4 \% \mathrm{P}, \mathbf{8 7 . 4} \%$ collagen $(\mathrm{N} \times 5.53)$ and hence $5.0 \% \mathrm{P}$ on collagen basis which corresponds to 1.61 meq. PMP per g collagen. Since the combining capacity of collagen for acids is equal to $0.94 \mathrm{meq}$ per $\mathrm{g}$ collagen, the average combining weight of PMP expressed as $\mathbf{P}$ is 53. The sodium content was $1.56 \% \mathrm{Na}$, based on collagen, which corresponds to 5 atoms of $\mathrm{Na}$ on 12 atoms of $\mathrm{P}, i$. e., an equivalent of $\mathrm{P}=54$ assuming complete interaction of the free $\mathrm{P}-\mathrm{O}^{-}$groups with the cationic protein groups. The agreement between the equivalent weights figured from the data of the $\mathbf{P}$ content, on one hand, and from the value of sodium, on the other hand, is better than could be expected.

Finally some data on the uptake of the PMP-anions from solutions of sodium polymetaphosphate with constant ratio of $\mathrm{NaPO}_{3}: \mathrm{HCl}$ at varying $\mathrm{pH}$ values are given in Table 2. The reactivity of solutions of $\mathrm{HCl}$-adjusted polymetaphosphate towards hide powder at increasing PMP-concentration is illustrated by the data of Table 3. In both 


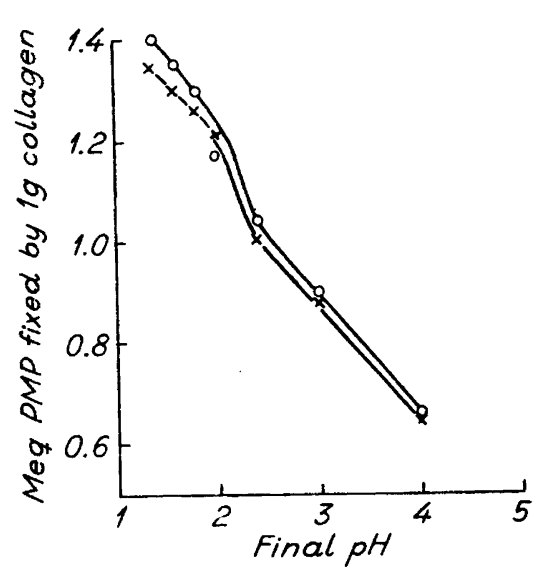

Fig. 3. The irreversible fixation of ionexchanged polymetaphosphoric acid by hide powder, expressed in meq $P$ fixed by $1 \mathrm{~g}$ collagen, as a function of equilibrium $p H$.

$I-\mathrm{O}-\mathrm{O}-\mathrm{O}-: d i r e c t$ determination of $P$ in substrate.

$I I-\times-\times-x-$ : indirect determination of equivalents PMP fixed by $1 \mathrm{~g}$ collagen from alkalimetric titration of initial and residual solutions.

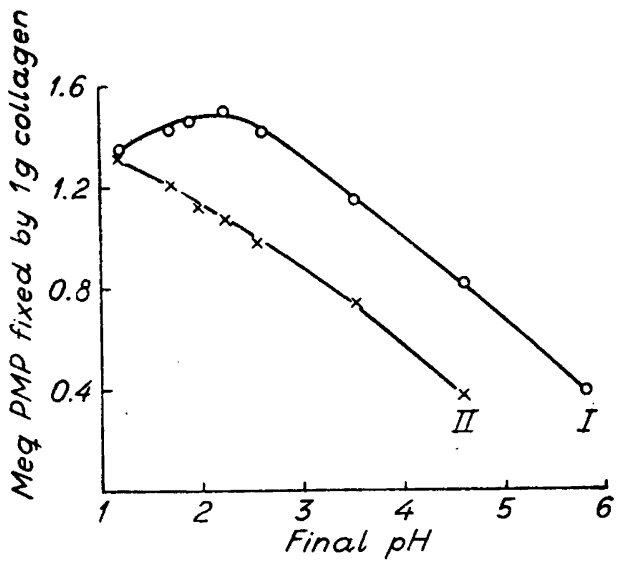

Fig. 4. The irreversible fixation of PMP by hide powder from acidified solutions of sodium polymetaphosphate expressed in meq $P$ fixed by $1 \mathrm{~g}$ collagen, as a function of equilibrium $\mathrm{pH}$.

$I-\mathrm{O}-\mathrm{O}-\mathrm{O}-: d i r$ e $t$ determination of $P$ in substrate

$I I-\times-\times-\times-$ : indirect determination of equivalents PMP fixed by $1 \mathrm{~g}$ collagen, from alkalimetric titration of initial and residual solutions.

series portions of hide powder $=1 \mathrm{~g}$ collagen were shaken for $8 \mathrm{~h}$ with $25 \mathrm{ml}$ of the solution. The equivalents of PMP fixed were determined directly by P-determination on the washed specimens and indirectly by the difference in the acid content of the original and residual solutions.

Table 2. Fixation of PMP-acid from solutions of constant ratio $\mathrm{NaPO}: \mathrm{HCl}$ (5:2).

$\begin{array}{ccccc} & & \text { meq } P \text { fixed } & \text { meq } P \text { fixed by } 1 \mathrm{~g} \\ \text { No. } & \text { Normality of } & \text { Final } & \text { by } 1 \mathrm{~g} \text { collagen } & \text { collagen (alkalimetric) } \\ \text { solution in } \mathrm{P} & \mathrm{pH} & \text { (P-determination) } & \text { indirectly }\end{array}$

\begin{tabular}{lllll}
1. & 0.1 & 1.8 & 1.46 & 1.02 \\
2. & 0.2 & 1.5 & 1.65 & 1.20 \\
3. & 0.4 & 1.2 & 1.68 & 1.18 \\
4. & 0.6 & 1.0 & 1.72 & 1.20 \\
\hline
\end{tabular}


Table 3. Fixation of $\mathrm{PMP}$-acid from solutions of constant $\mathrm{Cl}^{-}$-concentration at varying PMP.content.

\begin{tabular}{lccccc}
\hline No. & $\begin{array}{c}\text { Normality of solution } \\
\text { in P }\end{array}$ & $\begin{array}{c}\text { Final } \\
\text { in } \mathrm{Cl}\end{array}$ & $\begin{array}{c}\text { meq P fixed by } \\
\mathrm{lg} \text { collagen } \\
\text { (P-determination) }\end{array}$ & $\begin{array}{c}\text { meq P fixed by } 1 \mathrm{~g} \\
\text { collagen (alkalimetric) } \\
\text { indirectly }\end{array}$ \\
\hline & & & & & \\
1. & 0.1 & 0.06 & 2.05 & 1.43 & 1.09 \\
2. & 0.2 & 0.06 & 2.0 & 1.65 & 1.05 \\
3. & 0.4 & 0.06 & 2.0 & 1.68 & 1.00 \\
4. & 0.6 & 0.06 & 1.95 & 1.75 & 0.96 \\
\hline
\end{tabular}

Evidently the uptake of PMP by collagen from solutions of $\left(\mathrm{NaPO}_{3}\right)_{n}$ with varying $\mathbf{P}$-content and $\mathrm{H}$-ion concentration is practically the same in P-concentrations from 0.2 to $0.6 \mathrm{~N}$ and in the $\mathrm{pH}$ range $1.0-1.5$. This is also the case in the syste. $x_{j}$ with constant $\mathrm{Cl}$-ion concentration (added $\mathrm{HCl}$ ) and equilibrium $\mathrm{pH}$, varying the concentration of the PMP. The large difference of the bound PMP found by the two methods is noteworthy; anew demonstrating the erroneous results obtained in figuring the degree of inactivation of the basic groups of the protein by means of equivalents of $P$ (from data of the $\mathrm{P}$ content of the PMP-protein).

2. The effect of hydrochloric acid on PMP-collagen.

As an illustration of the application of other reactions to the PMP-collagen, its behaviour to solutions of $0.1 \mathrm{~N} \mathrm{HCl}$ is of interest. Generally, the degree of inactivation of the basic groups of collagen by an anionic agent present in stable combination with collagen is conveniently evaluated by assessing the meq of $\mathrm{HCl}$ removed from a $0.1 \mathrm{~N}$ solution in contact with the collagen with partly inactivated cationic groups. This method works well for polysulphonic acid dyestuffs and high-molecular lignosulphonic acids ${ }^{18}$. In the case of PMP-treated collagen, particularly specimens prepared in strongly acidic solutions, many complications enter; in the latter instance particularly the exchange of PMP-anions for $\mathrm{Cl}$-ions besides the removal of $\mathrm{H}$ ions by any carboxyl ions of collagen remaining free. Although the displacement reaction does not enter so markedly in the HCl-treatment of PMP-collagen prepared from acidified PMP solutions of $\mathrm{pH} 2.4-3.5$, the sodium atoms contained in the PMP chains introduce an additional error.

In the present instance the aforementioned specimen containing $1.61 \mathrm{meq}$ $\mathbf{P}$ in combination with collagen, in an amount equal to $1 \mathrm{~g}$ collagen, was shaken for $6 \mathrm{~h}$ in $20 \mathrm{ml} 0.1 \mathrm{~N} \mathrm{HCL}$-solution. The amounts of $\mathrm{H}$ - and Clions of the residual solution were determined. It was $0.1 \mathrm{~N}$ in regards to Cl-ions and further a quantity of $9 \mathrm{mg} P$ was found. Hence, $0.29 \mathrm{meq} P$ was displaced; 
that is, 18 per cent of the total $P$ content of the substrate had gone into solution. Since the concentration of $\mathrm{Cl}$-ions of the solution remained the same, no free basic protein groups were present. On the other hand, $0.46 \mathrm{meq} \mathrm{H}$-ion was removed from the solution, probably displacing the greatest part of the sodium atoms of the fixed PMP. Evidently the large PMP anions are split into smaller fragments by means of the $\mathrm{H}$-ions; no direct action of $\mathrm{Cl}$-ions being apparent.

Similar experiments were run with hide powder equilibrated with solutions of acidified PMP at final $\mathrm{pH}$ values of 2.0 and 1.4 .

The following figures are worthy of notice. The specimen treated at $\mathrm{pH} 2.0$ contained $4.5 \% \mathrm{P}$ and $0.95 \% \mathrm{Na}$, figured on collagen. The meq of PMP fixed were 1.45 (P-determination) and 1.00 (alkalimetric titration). Further, this PMP.hide powder $(=1 \mathrm{~g}$ collagen) removed $0.21 \mathrm{meq} \mathrm{H}^{+}$and $0.10 \mathrm{meq} \mathrm{Cl}^{-}$from solutions of $0.1 \mathrm{~N} \mathrm{HCl}$, loosing 0.37 meq $\mathrm{P}$, indicating displacement of $\mathrm{Na}$ - for $\mathrm{H}$-ions as well as PMP-anions for $\mathrm{Cl}$-ions and also a minor removal of $\mathrm{H}$ and $\mathrm{Cl}$ ions by the free anionic and cationic protein groups. This example is cited to show the difficulties encountered in the interpretation of such experimental data.

Finally, the hide powder reacted with PMP in a solution containing equivalent amounts of $\mathrm{NaPO}_{3}$ and $\mathrm{HCl}$, at a final $\mathrm{pH}$ value of 1.4, gave the following figures: Its $P$ content was 4.05 on the weight of collagen, corresponding to $1.31 \mathrm{meq} P$ and the titrometrically determined content of $P$ was 1.26 meq $P$. The sodium content was only $0.08 \mathrm{meq} \mathrm{Na}$ per $\mathrm{g}$ collagen. By treating $1 \mathrm{~g}$ collagen in the form of the PMP-collagen in $25 \mathrm{ml} 0.1 \mathrm{~N} \mathrm{HCl}$ for $6 \mathrm{~h}$, no $\mathrm{H}$-ions were taken up. An amount of $\mathrm{Cl}$-ions equal to 0.24 meq was removed by the substrate. Alkalimetrically the residual solution was $0.108 \mathrm{~N}$ containing displaced PMP, which amounted to 0.41 meq $P$. This example shows anew that good agreement of the equivalent weights of $\mathrm{P}$ of the PMP fixed at low $\mathrm{pH}$ values is obtained by $P$-determination on the substrate and by alkalimetric titration of the system since formation of complexes containing sodium is practically eliminated. It is of interest to note that the PMP fixed by collagen at low $\mathrm{pH}$ values is much more easily displaced by $\mathrm{HCl}$ and may be gradually removed upon prolonged washing than is the case with specimens equilibrated with PMP at moderate $\mathrm{pH}$ values (about 3). Evidently the breaking up of the large molecules of PMP in solutions of the low $\mathrm{pH}$ range is largely responsible for the instability of the phosphate-collagen compound. This is still more evident from the behaviour of collagen treated in pure PMP acid solution and furthermore accentuated in specimens which have been brought to react with such solutions of $\mathrm{pH} 1.3-1.4$ standing $24-4.8 \mathrm{~h}$ before application. Anew, it is proved that the molecular size of the fixed PMP is a main factor determining the degree of stability of the PMP. protein compound. This problem is under further investigation.

3. The effect of sodium chloride on PMP-collagen.

Another unique type of displacement of the irreversibly fixed PMP from the collagen lattice is effected by short treatment of PMP-collagen in solutions of sodium chloride, a $2 M \mathrm{NaCl}$ solution being effectively employed, first noted by Schneider ${ }^{26}$. Taking as an example the specimen equilibrated with 
PMP solutions of final $\mathrm{pH}$ 2.4, the following data are of interest. A portion of $3 \mathrm{~g}$ of dry PMP-hide powder was shaken for $24 \mathrm{~h}$ in $100 \mathrm{ml} 2 \mathrm{M}$ solution of $\mathrm{NaCl}$. The treated powder was then washed until the wash water became free from Cl-ions. The percentage of combined $\mathrm{P}$, figured on the weight of collagen, was then reduced from 5.0 to 2.3 and the amount of sodium from $1.56 \%$ $\mathrm{Na}$ to $0.06 \%$. Hence, it appears as the PMP-chains containing sodium are preferentially removed in the salt treatment. The identical treatment of PMP-hide powder equilibrated in $0.1 \mathrm{~N}$ solution of pure PMP acid, showed the following figures. The original specimen contained $3.2 \% \mathrm{P}$ or $1.03 \mathrm{meq}$ PMP acid per g collagen. After treatment in $2 M \mathrm{NaCl}$-solution and subsequent washing, it analyzed $0.3 \% \mathrm{P}$ on collagen basis, showing $94 \%$ displacement of the fixed PMP acids. Also in this instance it is clear that the PMP-collagen compound obtained from the solution of PMP of low $\mathrm{pH}$ values is easier hydrolyzed than the PMP-compound of collagen introduced from solutions of higher $\mathrm{pH}$ values. Finally, the nature of the displacing effect of sodium chloride on the PMP fixed by collagen will be exemplified.

Hide powder equilibrated with ion-exchanged polymetaphosphoric acid at pH 1.4 containing $1.23 \mathrm{meq} P$ (by $P$-determination) and $1.28 \mathrm{meq} P$ (by alkalimetric titration) per g collagen was treated in $2 \mathrm{~g}$ portions in $80 \mathrm{ml} 2 \mathrm{M} \mathrm{NaCl}$ solution for $24 \mathrm{~h}$. The residual solution and the wash water were made up to $100 \mathrm{ml}$. The filtrate contained $0.78 \mathrm{meq} \mathrm{H}^{+}$and $2.32 \mathrm{meq} \mathrm{P}$ (on $2 \mathrm{~g}$ collagen). Analysis of the treated hide powder gave $0.06 \mathrm{meq} P$ per $\mathrm{g}$ collagen. Accordingly $95 \%$ of the fixed PMP was removed in the treatment. Further, the treated stock contained $0.84 \mathrm{meq} \mathrm{H}^{+}$ions per g collagen $(1.23-0.39)$ in the form of hydrochloric acid. Thus, the main reaction is an exchange of anions, $\mathrm{Cl}$ ions displacing PMP anions in the collagen lattice. It is simply a mass action effect.

The average molecular weight of the displaced polymetaphosphoric acid was determined by end group titration. It showed an average molecular weight of 2000-2500. The method was checked on solutions of ion-exchanged polymetaphosphoric acid of various concentrations and in the presence of sodium chloride. The data obtained in Table 4 show that the presence of 2 mol $\mathrm{NaCl} / 1$ of the solution has no effect on the end group titration. Similar titrations on PMP displaced by $\mathrm{NaCl}$ from PMP-collagen equilibrated with acidified sodium PMP of pH 3.0 gave molecular weights of 3000-3500.

The decrease of the $\mathrm{pH}$ value of no 3 from 2.4 to 1.8 by making the solution $2 M$ in regards to $\mathrm{NaCl}$ is due to the hydrochloric acid formed. The decreasing effect of neutral chlorides, particularly sodium chloride, upon the fixation of PMP by collagen has been proved by Riess, Schneider and Salo, who determined the total amount of polymetaphosphate taken up by collagen and not 
Table 4. End group titration of solutions of polymetaphosphoric acid.

\begin{tabular}{|c|c|c|c|c|c|c|c|c|}
\hline No. & & Soluti & ions & & $\begin{array}{c}\text { Initial } \\
\mathrm{pH}\end{array}$ & $\begin{array}{c}\text { Total ml } 0.1 N \\
\mathrm{NaOH} \text { consumed } \\
\text { (to pH 5.6) }\end{array}$ & $\begin{array}{c}\mathrm{ml} 0.1 \mathrm{~N} \mathrm{NaOH} \\
\text { consumed from } \\
\mathrm{pH} 5.6 \text { to } 8.6\end{array}$ & $\begin{array}{c}\text { Average } \\
\text { mol. } \\
\text { weight }\end{array}$ \\
\hline \multicolumn{5}{|c|}{ 1. $0.1 \quad N$ PMP-acid (ion exchanged) } & 1.35 & 52.8 & 3.8 & 2800 \\
\hline 2. $0.02 N$ & $"$ & $"$ & $"$ & $"$ & 2.1 & 10.8 & 0.88 & 2500 \\
\hline 3. $0.01 N$ & $"$ & $"$ & $"$ & " & 2.4 & 5.76 & 0.60 & 2000 \\
\hline \multirow{2}{*}{$\begin{array}{l}\text { 4. } 0.01 \mathrm{~N} \\
\text { containing }\end{array}$} & $"$ & $"$ & 4 & $"$ & & & & \\
\hline & ng 2 & $\mathbf{M} / \mathbf{1}$ & $\mathrm{NaCl}$ & & 1.8 & - & 0.60 & 2000 \\
\hline
\end{tabular}

the total amount of acid equivalents removed from the solutions with added sodium chloride. With increasing concentrations of $\mathrm{Cl}$ ions of the solution of acidified PMP or free polymetaphosphoric acid, pelt will take up more and more acid in the form of hydrochloric acid; the final effect being to keep the equivalents of total acid fixed constant or in some instances to increase it, compared to the equivalent fixation of the PMP-acid. Hence, it is also evident that in the system of acidified PMP, the increasing amounts of sodium chloride formed with increased acidity will have a slight lowering effect on the fixation of the PMP-compound. However, as previously mentioned no chloride ions are taken up by hide powder from the system $\mathrm{NaPO}_{3}-\mathrm{HCl}$ of initial $\mathrm{pH}$ values $1.3-5.0$.

As an example of the preferential fixation of Cl-ions in the presence of large excess of salt, the following data are interesting. Portions of $1.0 \mathrm{~g}$ collagen as hide powder were treated for $6 \mathrm{~h}$ in $50 \mathrm{ml} 0.05 \mathrm{~N}$ ion-exchanged polymetaphosphoric acid and further in the same solution made $2 M$ in $\mathrm{NaCl}$. The $\mathrm{pH}$ of the residual solution from the pure acid treatment was 2.0, that of the $2 M \mathrm{NaCl}$ exhaust 1.3. The milliequivalents fixed PMP per g collagen were 1.15 and 0.24 respectively; the latter specimen containing an additional amount of acid ( $\mathrm{HCl}$ ) equal to $0.75 \mathrm{meq}$ per $\mathrm{g}$ collagen. In both instances, the maximum acid binding capacity of collagen was satisfied.

\section{The effect of PMP fixed by collagen on its hydrothermal stability.}

The irreversible fixation of PMP by collagen even at $\mathrm{pH}$ values as low as 1.5, does not produce swelling of the hide substrate, rather dehydration of the isoelectric protein is effected. Thus, hide powder completely hydrated in water at $\mathrm{pH} 5.8$ contained after removal of superfluous water by suction on a glass filter under standardized conditions, $2.3 \mathrm{~g}$ water per $\mathrm{g}$ collagen, whereas 
hide powder equilibrated with $0.1 \mathrm{~N}$ ion-exchanged polymetaphosphoric acid of $\mathrm{pH} 1.5$ contained $2.0 \mathrm{~g}$ water per $\mathrm{g}$ collagen, determined under identical experimental conditions. Hide powder treated with the $0.1 \mathrm{~N}$ polymetaphosphoric acid solution after heating it to $95^{\circ} \mathrm{C}$ for $5 \mathrm{~min}$., swelled considerably and turned glue-like, probably due to the formation of scission products reacting unifunctionally with collagen. The treated hide powder contained $6.2 \mathrm{~g}$ water per $\mathrm{g}$ collagen. Similar experiments were run on iso-electric calf skin pelt, which after $24 \mathrm{~h}$ treatment in water and following pressing under standardized conditions contained $1.7 \mathrm{~g}$ water per $\mathrm{g}$ collagen. By pretreatment in $0.1 \mathrm{~N}$ polymetaphosphoric acid, the value of 1.5 was recorded, whereas the corresponding treatment in the solution boiled before use was $8.5 \mathrm{~g}$ water per g collagen. These simple experiments show that the nonswelling action and the dehydrating effect of PMP-compounds are intimately bound up with the polyfunctional interaction of large molecules of PMP. The split products produced upon keeping the solutions for long time at room temperature or upon brief heating are not irreversibly fixed and offer conditions of attachment to collagen favourable for the establishment of Donnan effects (swelling) which require completely reversible systems and low affinity of the reacting anion for the cationic protein groups. In this connection, the effect of storing of hide powder originally in irreversible combination with ion-exchanged polymetaphosphoric acid in slightly moist state $(20 \%$ moisture) for 12 months on its stability is of interest. Treating the aged specimen ( $1 \mathrm{~g}$ in $200 \mathrm{ml}$ water) two consecutive times, each $24 \mathrm{~h}, 42$ per cent of the originally fixed PMP was washed out, indicating a gradual formation of scission products from the condensed phosphoric acid originally fixed by collagen.

The postulate of the polyfunctional attachment of PMP on collagen and the resulting stabilization of the protein lattice by the rivetting together of adjacent protein chains by one large chain of PMP is given additional support by the data on the effect of the fixed PMP on the hydrothermal stability of collagen. Portions of strips of isoelectric calf skin pelt in duplicates $(20.0 \mathrm{~g}$ pressed weight $=6.0 \mathrm{~g}$ collagen) were shaken for $20 \mathrm{~h}$ in $100 \mathrm{ml}$ of a $2 \%$ solution of sodium polymetaphosphate (M.W. 6800) of various $\mathrm{pH}$ values, adjusted by means of hydrochloric acid (initial $\mathrm{pH}$ : $1.3-5.8$ ). The residual solution was drawn off and the $\mathrm{pH}$ determined. The treated pelt was then washed, alternating with shaking in water in several runs. The residual solution and the wash water of the duplicate was made up to $1000 \mathrm{ml}$ for alkalimetric determination of the PMP remaining in the solution. As a measure of the hydrothermal stability the shrinkage temperature $\left(T_{s}\right)$ is generally used. The $T_{s}$ was determined both on the freely suspended strips and on strips with both ends fastened in a shrinkage tester, the latter mode of determination 
Fig. 5. The irreversible fixation of PMP by calf skin pelt from acidified solutions of sodium polymetaphosphate, expressed in meq $P$ fixed by $1 \mathrm{~g}$ collagen, as a function of equilibrium $\mathrm{pH}$.

I -O-O-O- : direct determination of $P$ in substrate

II $-\times-x-\times-$ indir e ct determination of equivalents PMP fixed by $1 \mathrm{~g}$ collagen, from alkalimetric titration. of initial and residual solutions.

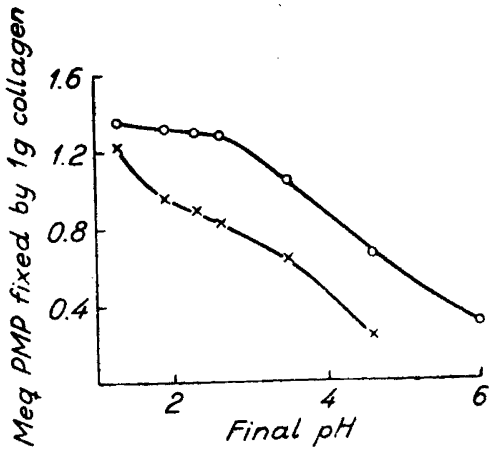

giving $2-3^{\circ} \mathrm{C}$ higher values. However, the difference recorded in shrinkage temperature, $\triangle T_{s}$, of the various specimens by the two methods showed good agreement $\left(0.5^{\circ} \mathrm{C}\right)$. The results of these series are given in Table 5 .

Table 5. The interaction of acidified sodium polymetaphosphate with calf skin pelt.

\begin{tabular}{|c|c|c|c|c|c|}
\hline No. & $\begin{array}{c}\text { Final } \\
\text { pH }\end{array}$ & $\begin{array}{c}\text { meq P fixed by } \\
1 \mathrm{~g} \text { collagen } \\
\text { (indirectly by } \\
\text { alkalimetric titration } \\
\text { of solutions) }\end{array}$ & $\begin{array}{l}\text { meq } P \text { fixed by } \\
1 \mathrm{~g} \text { collagen } \\
\text { (from direct } \\
\mathbf{P} \text { determination } \\
\text { of treated pelt) }\end{array}$ & $\begin{array}{l}\text { meq Na per } \\
g \text { collagen }\end{array}$ & $\Delta T_{s}$ \\
\hline 1. & 1.3 & 1.24 & 1.36 & 0.04 & +5 \\
\hline 2. & 1.9 & 0.96 & 1.32 & - & +4 \\
\hline 3. & 2.3 & 0.90 & 1.30 & - & +4 \\
\hline 4. & 2.6 & 0.82 & 1.29 & - & +3.5 \\
\hline 5. & 3.5 & 0.64 & 1.05 & 0.31 & +3 \\
\hline 6. & 4.6 & 0.32 & 0.67 & - & 0 \\
\hline 7. & 6.0 & - & 0.30 & - & -7 \\
\hline 8. & & $\begin{array}{ll}\text { (ion ex- } & 1.32 \\
\text { changed } & \\
\text { PMP-acid) } & \end{array}$ & 1.26 & 0.00 & 0 \\
\hline
\end{tabular}

Also in these series the direct P-determination and the indirect alkalimetric estimation of the fixation of PMP, expressed in meq per $g$ collagen, shows large differences in systems of $\mathrm{pH}$ values greater than 1.3 as evident from the graphs of Fig. 5. Regarding the main theme, the effect of the PMP treatment on the $T_{s}$ of the skin, it is evident that the PMP fixed by collagen from systems of low $\mathrm{pH}$ values is most effective in raising the $T_{s}$, which in this instance 
probably partly reflects the fact of the more complete inactivation of the basic protein groups at the highest $\mathrm{H}$-ion concentration. Thus, the potential of anionic centers of the PMP-chains is more fully made use of and hence the protein chains are rivetted together more extensively. Of particular importance is the considerable lowering of the $T_{s}$ of collagen induced by the unadjusted PMP-solution ( $\mathrm{pH}$ 5.5-6.0) which actually has a hydrotropic effect, also shown by the swelling of the pelt ${ }^{19}$. This swelling is to a large extent permanent and apparently belongs to the lyotropic class of ion and molecular effects, shown by strong solutions of urea, thiocyanates and halogen salts, particularly of bivalent metals. Then, illustrations are given on the stabilizing effect of a polyfunctional, irreversibly fixed large anion on the collagen lattice, on one hand, and the opposite behaviour of an unifunctional anion, which by its fixation on collagen weakens the intermolecular cohesion of the native protein by breaking crosslinks originally present, on the other hand: This problem and the behaviour of related compounds will be further discussed in next section.

By keeping pelt no. 1 in toluene-saturated water for 6 months at $4^{\circ} \mathrm{C}$, it showed marked swelling and peptization, probably due to the formation of low-molecular acids (including phosphoric acid). Hence, PMP-treated collagen should be immediately dehydrated (acetone) and stored in this conditions in order to eliminate secondary splitting of the large PMP-molecules in the protein lattice.

It has erroneously been claimed ${ }^{9}, 20$ that free PMP-acid swells hide. That is not the case if the solutions of ion-exchanged acid (from sodium salts of molecular weights 3000-8000) are used immediately after preparation, limiting the time of interaction with collagen to $24-48 \mathrm{~h}$. By the formation of hydrolysis products of the acids, occurring gradually upon storing the solutions or rapidly by heating, swelling of hide is promoted, as shown earlier.

\section{COMMENTS}

Restating facts, the main finding of this investigation is that in the reaction of collagen and acidified solutions of sodium polymetaphosphate molecular chains of PMP of varying length and proportions of $\mathrm{H}$ and $\mathrm{Na}$ ions associated with the $\mathrm{PO}^{-}$-groups, governed by time, $\mathrm{pH}$ and other factors, are taken up and irreversibly fixed by collagen. The degree of inactivation of the basic protein groups measured in equivalents fixed PMP (alkalimetrically) by collagen shows steady increase with decreasing $\mathrm{pH}$ of the reacting systems, being complete at final $\mathrm{pH}$ values about 1.5. The generally accepted view of an optimum range of reactivity in the vicinity of $\mathrm{pH} 2.4$ of the equilibrated 
PMP solution is needy of revision, being a measure of the total fixation of PMP; overlooking the numerous $\mathrm{PO}^{-}$-units which cannot function as anionic centers for the interaction with cationic protein groups on account of the association of sodium ions with the former groups and unfavourable steric environment of the reactive $\mathrm{PO}^{-}$groups for discharge of electropositive groups of collagen. Thus, such high values of fixed $\mathrm{P}$ as 1.6-1.7 meq per $\mathrm{g}$ collagen obtained upon direct $\mathbf{P}$ determination of the substrate are explained. It is also obvious that any simple stoichiometric relationship of the PMP compounds fixed is not discernible since, for instance, in a chain of 30 units the proportion of $\mathrm{Na}$ to $\mathrm{H}$ will vary continuously according to the proportion of hydrochloric acid added to Na-PMP. Hence, it is only a coincidence that the composition of the compound fixed at $\mathrm{pH} \mathrm{4}$, in one case found, corresponds most closely to the formula: $\left(\mathrm{Na}_{4}\left(\mathrm{PO}_{3}\right)_{6}\right)_{x}$. The marked affinity of sodium for the $\mathrm{P}-\mathrm{O}$-ion is responsible for the fact that from solutions of $\mathrm{pH}$ values $2-1.5$, with nearly one equivalent of $\mathrm{HCl}$ added per equivalent $\mathrm{NaPO}_{3}$ in the last instance, small amounts of $\mathrm{Na}$ is present in the anions fixed by collagen.

Regarding the average molecular weight of the PMP attached to collagen, no definite figures are available. However, in treatment of collagen in solutions adjusted to $\mathrm{pH} 3-4$ directly after preparation and limiting the time of interaction to a few hours, the average molecular weight of the original PMP is only slightly lowered and large molecules probably are interacting with collagen. In solutions of pure polymetaphosphoric acid, working in the $\mathrm{pH}$ range of 2.0-2.5, hydrolysis of the large molecules evidently takes a rapid course although practically no $\mathrm{PO}_{4}$ ions are formed. Since gelatin still precipitates these solutions after $4-8 \mathrm{~h}$ standing, $i . e$. , the time of interaction with the protein generally employed and also the benzidine test is positive, part of the PMP combining with collagen probably remains as rather large molecules. This is also brought out by the marked stabilization effect of PMP, reacting with hide substance in this $\mathrm{pH}$ range, as evident by the $T_{s}$ figures and also by their dehydrating effect.

A comparison with other anionic agents is illuminating. A strong mineral acid, such as $\mathrm{HCl}$, forming a reversible system with collagen, swells hide and lowers its $T_{s} 30-40^{\circ} \mathrm{C}$. The strong unifunctional acid, $\beta$-naphthalene sulphonic acid, reacting at $\mathrm{pH}$ 1.4, possesses affinity for the cationic protein groups solely, being partly irreversibly fixed. It does not swell hide. On the other hand, complete inactivation of basic protein groups by means of this acid (breaking completely the ionic crosslinks of collagen) decreases the $T_{s} 16-$ $18^{\circ} \mathrm{C}$; accounted for by the discharge of the carboxyl ions of collagen and the inactivation of the basic protein groups by the anion of the acid ${ }^{22}$. A bifunctional acid is formed from the naphthalene sulphonic acid by condensing it 
by means of formaldehyde, dinaphthalene methylene disulphonic acid, which does not swell collagen and which only exerts a slight $T_{s}$-decrease. By further condensation polynaphthalene compounds of disulphonic acids are formed which stabilize collagen to a minor degree, judging from the improved hydrothermal stability.

This effect is also shown by the highmolecular fractions of lignosulphonic acids. Their interaction with collagen is remarkable since the large number of sulphonic acid groups interspaced in a large molecule practically quantitatively react with the basic protein groups. Thus, preparations of average molecular weights of $8000-10000$, containing from 16 to 20 sulphonic acid groups in a single molecule, show an average combining weight to collagen equal to the equivalent weight of the original acid ${ }^{23}$. Hence, the experimental findings from various sources do not disclaim the possibility of a large chainlike molecule with numerous, active anionic groups being introduced into the collagen lattice. The binding of lignosulphonic acid by collagen appears to be an ionic reaction in the initial stage. However, it is indicated that the electrovalent links formed are rapidly converted into a more stable binding, probably co-ordinate-covalent which resists the action of water, acids and neutral salts ${ }^{24}$. The linking of the PMP anion to the cationic protein groups apparently is of the electrovalent type and all evidence points to it remaining so. The anchorage of the long chain of PMP with its numerous anionic centers discharging adjacent basic protein groups should be expected to result in crosslinking of adjacent protein chains and hence will explain the irreversible nature of the reaction towards water, the improved hydrothermal stability and the lowered degree of water-binding imparted to the protein by the PMP-anion introduced into the collagen lattice. Also the easy replacement of the PMP anion in the collagen lattice by other anions, for instance, by means of treatment of PMP-collagen in concentrated solutions of neutral salts, conforms to the maintenance of the electrovalent linking of the original compound formed. It is a question of anion exchange.

From steric considerations of the availability of reactive protein groups to a single molecule of great length, certain objections may be raised against the concept of large multifunctional chains of PMP being the actual stabilizing agent. However, the presence of an $-\mathrm{O}-$ bridge for each $\mathrm{P}$ atom of the chain would be expected to impart a high degree of flexibility to the chain and hence adaptability to the cationic protein groups. Furthermore, the data obtained for the complete inactivation of cationic protein groups by means of polymetaphosphoric acids prove that only about two thirds of the $-\mathrm{O}-\mathrm{P}_{-}^{-}$ 
groups can find their oppositely charged partners of the protein (1.4 meq $P$ of $\left(\mathrm{HPO}_{3}\right)_{x}$ being required, whereas the theoretical figure is $\left.0.9 \mathrm{meq}\right)$. This is undoubtely a case of steric hindrance and what is more, it constitutes evidence for the existence of long-chain condensed phosphates in combination with collagen.

On the whole, the concept of introduction of polyfunctional PMP-chains into the collagen lattice is in harmony with our present knowledge of the properties of PMP-collagen. The view of Salo ${ }^{9}$, also subscribed to by Bear and his coworkers ${ }^{25}$ in a recent paper, assuming monomeric $\mathrm{HPO}_{3}$-units as the ultimate form of attachment of PMP on collagen has no experimental support and is improbable not only from the point of view of the existence of such a monomer being problematic but above all from the labilizing and swelling effect of simple phosphoric acid structures on collagen, in sharp contrast to the marked stabilization afforded by the PMP fixed.

In forthcoming papers the fixation of PMP by vegetable tanned collagen and by hide protein of various pretreatments will be reported as well as the important problem of the interaction of vegetable tannins with collagen in native state and with its basic groups completely inactivated by means of PMP. Further, investigations of the diffusion into heavy hide and fixation of different fractions of PMP, obtained by acetone fractionation according to Van Wazer are in progress.

\section{SUMMARY}

The interaction of sodium polymetaphosphate of average molecular weights of 3000-7000 with collagen, in aqueous solutions of PMP adjusted to $\mathrm{pH}$ values from 5 to 1.3 by means of hydrochloric acid as well as the corresponding reaction of ion-exchanged polymetaphosphoric acid have been investigated. The main findings are:

1. From solutions of acidified Graham's salt in the $\mathrm{pH}$ range 2.0-6.0 collagen fixes irreversibly PMP anions of varying composition which contain sodium, the relative amount of which increases with increasing $\mathrm{pH}$ of the reacting solution. The generally accepted view of maximum PMP interaction with collagen being reached at a final $\mathrm{pH}$ of 2.4 is incorrect. It is shown that the maximum degree of inactivation of the cationic groups of collagen requires $\mathrm{pH}$ values of 1.3-1.5 although the maximum amount of PMP fixed by hide powder, determined as $\mathrm{P}$, is at equilibrium $\mathrm{pH}$ of 2.4 , explained by the greater combining weights of the PMP of higher $\mathrm{pH}$ values. The interaction of polymetaphosphoric acid, free from foreign ions shows a steady increase of total amounts of $P$ fixed by collagen as well as of the equivalent fixation with decreasing $\mathrm{pH}$ of the system. 
2. The average molecular weights of the PMP present in acidified solutions of the sodium salt have been determined at $\mathrm{pH} 5.6,4,3$ and 2 by means of end group titration. The molecular weights of PMP in solutions of the natural $\mathrm{pH}$ of 5.6, were constant upon keeping; values of 3600 and 6800 being recorded for the two PMP preparations investigated. Only a slight lowering of the molecular weight was shown at $\mathrm{pH} 4.0$ upon time. PMP in solutions of $\mathrm{pH} 3$ is gradually broken down to smaller units, the change being insignificant upon $4 \mathrm{~h}$ keeping of the solution. On the other hand, in solutions adjusted to $\mathrm{pH} 2$ or less, the formation of splitting products is very marked, particularly for solutions of ion-exchanged polymetaphosphoric acid. By displacing the fixed PMP from its combination with collagen by means of concentrated solutions of sodium chloride, the PMP gone into solution showed average molecular weights of $2000-2500$.

3. The displacement of irreversibly fixed PMP from its combination with collagen by means of sodium chloride and the retarding effect of sodium chloride on the uptake of PMP by collagen is shown in the latter instance to be caused by the preferential fixation of $\mathrm{Cl}$ ions by collagen, a Donnan effect, and in the former instance to be a case of anion exchange, both reactions governed by the law of mass action. The easy removal of fixed PMP by electrolytes points to the initial electrovalent binding of PMP by collagen being retained in the final product.

PMP applied in solutions of $\mathrm{pH}<\mathbf{4 . 5}$ exerts a dehydrating effect on hide protein. Free PMP acid interacting with collagen directly after preparation does not swell collagen. On the contrary, it has a dehydrating action. The shrinkage temperature of hide is increased, up to $5^{\circ} \mathrm{C}$, by incorporation of PMP from solution of acidified PMP of final $\mathrm{pH}$ 1.3-4.0, with the optimum reached in the lower $\mathrm{pH}$ range. On the other hand, solutions of sodium polymetaphosphate of $\mathrm{pH}$ values 5-6, have a hydrotropic effect on collagen, inducing permanent swelling of hide and decreasing its shrinkage temperature $7-8^{\circ} \mathrm{C}$. The hydrothermal stabilization of hide protein by irreversible fixation of PMP indicates polyfunctional reactivity of the PMP and a probable crosslinking of adjacent protein chains.

4. The maximum acid binding equivalent of collagen; $0.9 \mathrm{meq} H$ ions per $\mathrm{g}$ collagen, is markedly exceeded in the fixation of polymetaphosphoric acid, saturation values of 1.2 to $1.3 \mathrm{meq}$ being recorded. This shows that not all of the available anionic centers of the PMP chains are able to interact with the cationic collagen groups. The reason is probably unfavourable steric conditions in the collagen lattice. The $\mathbf{P}$ fixed by collagen from solutions of $\mathrm{NaPO}_{3}-\mathrm{HCl}$ of $\mathrm{pH} 2.5-3.5$ corresponds to $1.6-1.7 \mathrm{meq}$ per $\mathrm{g}$ collagen. Besides the factor of steric hindrance, this high value can be attributed to the 
uptake of PMP anions containing $\mathrm{Na}$ and hence of anions of higher combining weight than that of polymetaphosphoric acid.

The incitation to the present investigation which has been carried out during the period 1943-1951 was given by the senior author's friend, the late Dr. John Arthur Wilson, New York, N. Y., the discoverer of the versatility of hexametaphosphates in tanning processes. This contribution is dedicated to his memory.

Grants from Statens Tekniska Forskningsråd are gratefully acknowledged.

\section{REFERENCES}

1. Schofield, R. K. Trans. Faraday Soc. 31 (1935) 390.

Samuel, L. W., and Schofield, R. K. Ibid. 32 (1936) 769.

2. Perlmann, G. J. Biol. Chem. 137 (1944) 707.

3. Briggs, D. R. Ibid. 132 (1940) 261.

4. Perlmann, G., and Hermann, H. Biochem. J. 32 (1938) 926.

5. Wilson, J. A. J. Am. Leather Chemists' Assoc. 32 (1937) 113, 494.

6. Riess, C. in Stiasny Festschrift. Roether, Darmstadt (1937) p. 366, Collegium 1938590.

7. Schneider, C. G. J. Am. Leather Chemists' Assoc. 42 (1947) 350; 44 (1949) 596; 45 (1950) 670.

8. Lindner, K. Collegium 1938, 145.

9. Salo, T. P. J. Am. Leather Chemists' Assoc. 45 (1950) 752.

10. Karbe, K., and Jander, G. Kolloid-Beihefte 54 (1942) 1.

11. Van Wazer, J. R., and coworkers. J. Am. Chem. Soc. 72 (1950) 639, 644, 647, 655 and 906; Ind. Eng. Chem. 41 (1949) 189.

12. Samuelson, O. Svensk Kem. Tid. 56 (1944) 343.

13. Gustavson, K. H. Acta Chem. Scand. 1 (1947) 581.

14. See especially for the potassium-salt, Ingelman, B., and Malmgren, H. Acta Chem. Scand. 1 (1947) 422; Malmgren, H. Ibid. 2 (1948) 147.

15. Lowry, P., and Lopez, J. J. Biol. Chem. 162 (1946) 421.

16. Lundegårdh, H. Die quantitative Spektralanalyse der Elemente, I and II. Fisher, Jena (1929 and 1934); Leaf analysis, Hilger and Watts, Ltd, London (1951).

17. King, E. J. Biochem. J. 26 (1932) 292. See Delany, G. E. Photoelectric methods in clinical biochemistry. Hilger, London (1949) p. 58.

18. Mickeley, A. in Stiasny Festschrift, Roether, Darmstadt (1937) p. 266; Ender, W., and Müller, A. Melliand Textilber. 18 (1951) 633; Gustavson, K. H., and Tomlinson, J. J. Soc. Leather Chem. 32 (1948) 165.

19. Riess, C. Collegium 1942305.

20. Riess, C. Collegium 1938590.

21. Lamm, O. Arkiv Kemi Mineral. Geol. 17 A (1944) no. 25.

Lamm, O., and Malmgren, H. Z. anorg. Chem. 245 (1940) 103.

22. Gustavson, K. H. Biochem. Z. 311 (1942) 347; Acta Chem. Scand. 4 (1950) 1171; J. Am. Leather Chem. Assoc. 46 (1950) 789.

23. Gustavson, K. H., and Larsson, A. in Festskrift tillägnad Erik Hägglund, Stockholm (1947) p. 101; Svensk Papperstidn. 50 (1947) 101.

24. Gustavson, K. H. Ing.vetenskapsakad. Handl. No. 177 (1944).

25. Bolduan, O., Salo, T. P., and Bear, R. S. J. Am. Leather Chem. Assoc. 46 (1951) 124.

26. Schneider, C. G. Ibid. 42 (1947) 350.

27. Steinhardt, J. Ann. N. Y. Acad. Sci. 41 (1941) 287.

Received May 18, 1951. 